\title{
Current Trends \& Challenges in Prosthetic Product Development: Literature Review
}

\author{
Stephen H. Rapp, PHD ${ }^{1}$, Nishant Pathak, MS $^{2}$, Aasish Yellapragada, $\mathbf{M S}^{3}$, Saurabh Gayakwad, MS ${ }^{4}$, \\ Mudit Gupta, $\mathbf{M S}^{5}$, Kailash Musunuru, $\mathbf{M S}^{6}$
}

\begin{abstract}
Bionic prosthetic limbs are rapidly advancing. In-depth knowledge of this field until recently, was only required by those working in specialized prosthetics. With evolving technology, it is likely that both demand and utilization of bionic limbs will increase, and more extensive understanding will be necessary. The bionic limb of today has progressed greatly, but it still endures high user abandonment (dismissal). The explanations behind dismissal, were deficient functionality of the equipment, compatibility with the subject, fragile design, and complex control methods. In the past decade, academia and industry have achieved real improvements in the technical features of bionic prosthetics limbs and techniques for bionic interface and control. Advanced robotic hands are offered by several organizations and research groups, with an assortment of active and passive wrist options customizable over several degrees of freedom. Currently, elbow joint designs incorporate dynamic arrangements with different weight and power alternatives. Control features are progressing in digital capability with options for sensor incorporation and multi-joint articulation. Recent advances in socket design are encouraging implantable and multiple surface electromyography sensors for customary and Osseo integration-based systems. Cost is a barrier affecting the usage of bionic prosthetics, particularly for support, repair and replacement, and constraints increasing component complexity to perform more distinct tasks. Lifetime costs of bionic prosthetic care are high. Furthermore, issues in quality, adaptability, continuance, and versatility are key factors that limits the usage of bionics. We present a literature review covering the current state of the bionic prosthetic limb market and its technical base for both technologies and techniques. We examine the functionality and features of the world's leading solution architectures and its impact on bionic product design. We do this in a value-added methodology exploring the body of knowledge for key areas underpinning the adoption of cutting edge bionic prosthetic technology. Finally, we provide a decision analysis model; recommendations for current research shortfalls; and future research needs.
\end{abstract}

Keywords: Prosthetics, Bionics, Artificial Limbs, Trends of Prosthetics, Advanced Bionics

\section{Introduction}

A bionic prosthetic is an artificial limb that enhances the function and lifestyle of the person with a missing body part. Bionic prosthetics help restore the normal function of missing limbs. Today artificial limbs can be controlled by computer, brain, and provide sensation with advanced technology. Rising incidence of fractures, increasing awareness among the people towards innovative technology, and high health care spending has fueled market growth. Rising awareness regarding the technology benefits of advanced prosthetics in the developing countries, high adoption of advanced products and growing use of novel materials for the manufacture of prosthetics are amongst few factors expected to drive demand for these devices.

\section{Market Scenario\& Bionic/Prosthetic Info}

\section{Market Scenario}

According to research, the bionic prosthetics market size was USD 790.8 million in 2016 and is expected to grow at a CAGR of $9.2 \%$ during the forecast period 2016-2027.A report published by the International Osteoporosis Foundation in 2017, stated that approximately one in three women and one in five men, aged over 50 years, are likely to suffer fragility fractures during their remaining lifetime. Rising prevalence of accidents, diabetes, vascular diseases, cancers, and congenital deformities leading to a surge in the amputee population, is one of the key factors anticipated to boost the market over the coming periods.

According to the data published by Graham $\mathrm{Z}$ in Amputee Coalition 1998, there are approximately 1.85 million amputations performed annually in the U.S.Statistic Brain Research Institute data shows $82 \%$ of amputations are performed due to vascular disease, $22 \%$ to trauma and $4 \%$ to congenital disabilities. A rise in prevalence of diabetes and vascular diseases, is anticipated to extend demand for prosthetics over the forecast period. According to Ziegler-Graham: Prevalence of Limb Loss in the United States are projected to increase from 1.6 million persons in 2005 to more thandoubleto 3.6 million in 2050 .

Also, new advanced products such as the SYMBIONIC LEG, RHEO KNEE, PROPRIO FOOT, and POWER KNEE are anticipated to raise product awareness in developed regions, such as North America and Europe, thus increasing the demand for such devices. Growing R\&D activities and increasing investment by private and public players to upgrade prosthetic products will help people affected by limb loss, achieve full body mechanical potential. Conversely, the increasing medical cost of bionics and poor reimbursement policies in the developing regions of the world will hinder market growth. These factors are compared in Figure 1 below. 


\section{International Journal of Science and Research (IJSR) \\ ISSN: 2319-7064}

ResearchGate Impact Factor (2018): 0.28 | SJIF (2018): 7.426

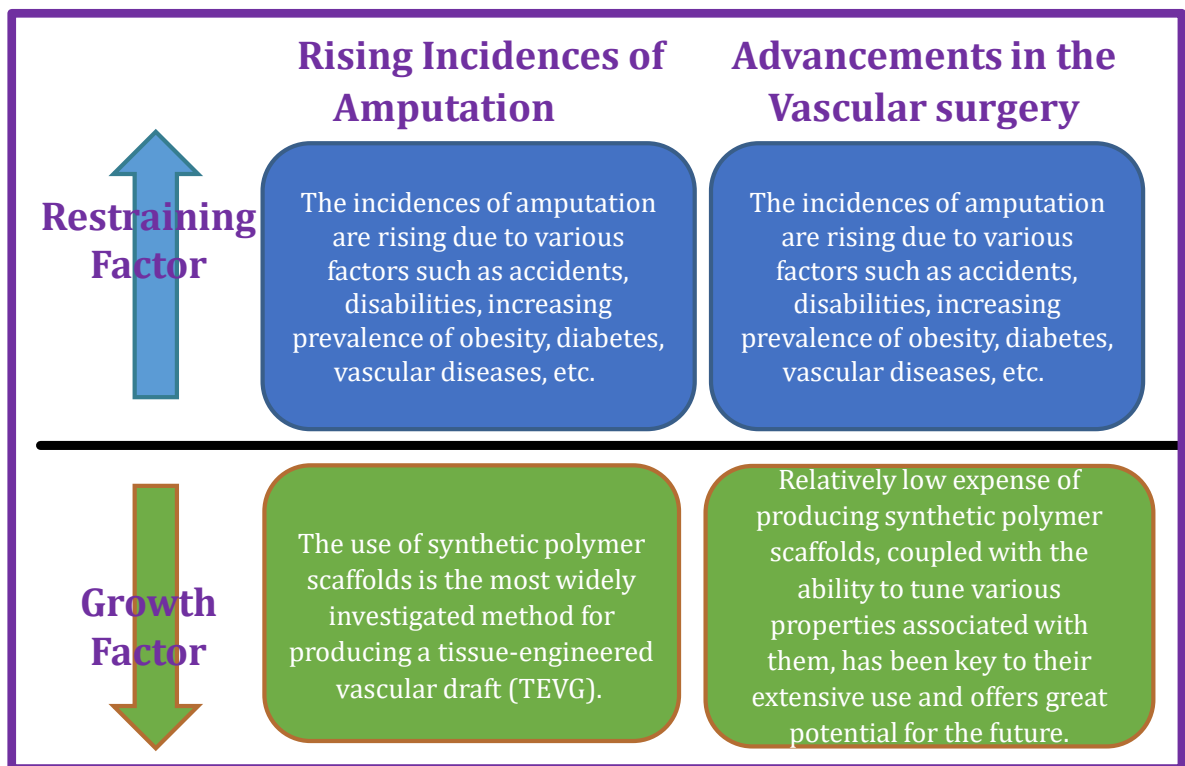

Figure 1: Factors Affecting the Prosthetic Market by both Amputation and Surgical Advance

The bionic prosthetics market is dominated by North America which includes USA and Canada. Key drivers owing to market growth include rising adoption of advanced products, surging numbers of amputees, increasing incidence of foot ulcers associated with diabetes, and favorable government initiatives for bionics to address healthcare expenses.

Europe holds the second position in the global bionic prosthetics market due to government support for development and availability of funds for research. This is expected to continue driving the European market over the forecasted period. For instance, countries like Germany and France are increasing investment in the healthcare domain.

The Asia Pacific is a huge market. Countries like India, the Philippines, Indonesia and China are experiencing fast growth due to their aging population, growing awareness about new technology, and availability of funds. Asia Pacific is the fastest growing market owing to huge diabetic population, quick economic development and improving healthcare infrastructure in emerging nations, notably India and China. Additionally, they are open to adopting new technology, and best treatment options to improve the quality of life for their citizens. Furthermore, increasing demand for quality devices in the healthcare is projected to lead to the use of advanced equipment, which, in turn, is likely to increase the market growth of the bionic prosthetics in the region. Increasing demand for quality product attract the focus of market players in this region, thus, they are introducing the advanced technology to maximize the profit in this region. Also, the lower cost of treatment in India attracts patient population from other countries.

Alternatively, the Middle East and Africa (MEA) region holds the lowest market share due to low investment and a poor healthcare infrastructure. See Figure 2 below for market area definition:

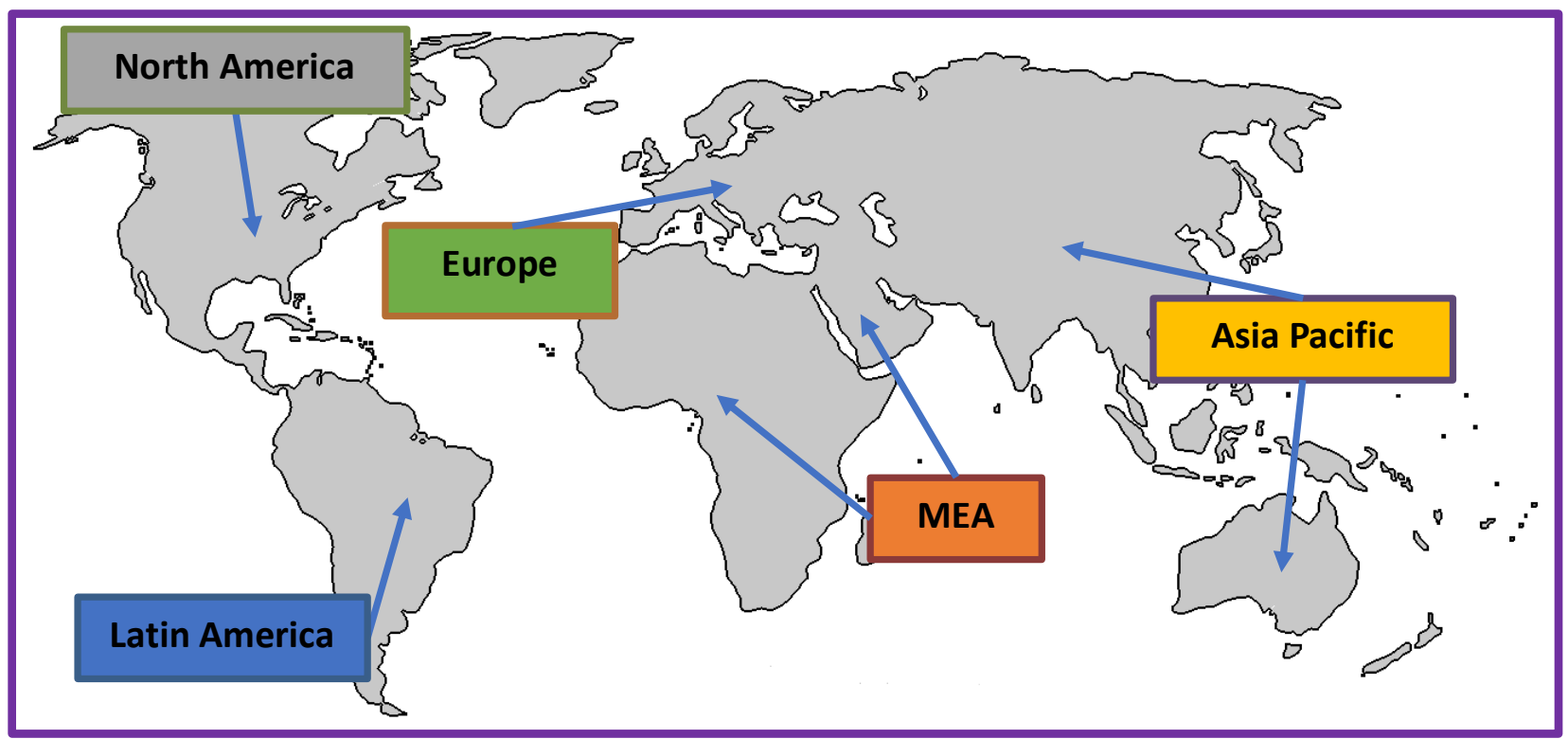

Figure 2: Major World Prosthetic Markets

Volume 8 Issue 6, June 2019 www.ijsr.net 


\section{International Journal of Science and Research (IJSR) \\ ISSN: 2319-7064}

ResearchGate Impact Factor (2018): 0.28 | SJIF (2018): 7.426

\section{Bionic Prosthetics}

The global bionic prosthetics market is segmented based on product, technology, application, and end user.

Based on product, it is segmented into prosthetic arms, prosthetic feet/ankles, prosthetic legs/knees, prosthetic hands, and others.

Based on technology, it is segmented into prosthetic foot materials, Bluetooth, microprocessor knees, myoelectric technology, and others.

Based on application, it is segmented into the lower body extremity and upper body extremity.

Based on end user, it is segmented into hospitals, clinics, and others.

\section{Current Technologies}

\section{Microprocessor Controlled Lower Limb Prostheses}

Microprocessor controlled knees offer dynamic control through sensors in the shin. Microprocessor controlled knees attempt to simulate normal biological knee function, by offering variable resistance control to the swing or stance phases of the gait cycle. This allows the user to safely perform ramp and stair descent in a stepover-step manner. The swing-rate adjustments allow the knee to respond to rapid changes in cadence. Microprocessor controlled knee flexion, enhances the stumble recovery capability of the patient, by preventing unexpected knee buckling. Prosthetic knees such as the microprocessor-controlled knee that focus on better control of flexion abilities, without reducing stability, have the potential to improve gait pattern, wearer confidence, and safety of ambulation. The microprocessor knee is more beneficial at higher ambulation speed in physically fit patients. Available devices include, but are not limited to, Otto-Bock C-Leg device ${ }^{\circledR}$, the OssurRheoKnee ${ }^{\circledR}$ or the Endolite Intelligent Prosthesis ${ }^{\circledR}$. A microprocessorcontrolled ankle foot prosthesis (e.g., Proprio Foot) can actively change the ankle angle and to identify sloping gradients and ascent or descent of stairs as the result of microprocessor-control and sensor technology.

\section{Myoelectric Prosthetic}

A myoelectric prosthesis uses electromyography signals or potentials from voluntarily contracted muscles within a person's residual limb via the surface of the skin, to control movement of the prosthesis, such as elbow flexion/extension, wrist supination/pronation or hand opening/closing of the fingers0. Prosthetics of this type utilize the residual neuro-muscular system of the human body to control the functions of an electric powered prosthetic hand, wrist or elbow. This type differs from the traditional electric switch prosthesis that requires body movement with mechanical devices to actuate or operate switches controlling prosthetic movement. Rather this type has a self-suspending socket, with pick up electrodes placed over flexors and extensors, for the movement of flexion and extension respectively.

\section{Literature Review}

All three tables below classify Artificial Limbs (Bionics and/VS, to show detailed, but summarized knowledge from each article regarding Prosthetics and Bionics) acrossmultiple categories. Table 1 coversboth mechanisms (process) and material while focusing on the combinedprosthetic process and material challenge. Tables 2 and 3 coverpure material improvements and by extension their specific challenges in prosthetic material improvement.

Table 1

\begin{tabular}{|c|c|c|c|c|}
\hline $\begin{array}{l}\text { Author/ } \\
\text { Topic }\end{array}$ & $\begin{array}{l}\text { Shuguang Li, Daniel M. Vogt, } \\
\text { Daniela Rus, and Robert J. Wood }\end{array}$ & $\begin{array}{c}\text { Roshan James, Cato T. } \\
\text { Laurencin }\end{array}$ & $\begin{array}{c}\text { Arthur F.T. Mak, PhD; Ming } \\
\text { Zhang, PhD; David A. Boone, } \\
\text { CP, MPH }\end{array}$ & $\begin{array}{l}\text { Christine Connolly Associate } \\
\text { Editor, Industrial Robot }\end{array}$ \\
\hline Information & \begin{tabular}{|c|} 
Proceedings of the National \\
Academy of Sciences Dec 2017, 114 \\
$(50)$ 13132-13137; DOI: \\
$10.1073 /$ pnas.1713450114 \\
\end{tabular} & $\begin{array}{l}\text { Regenerative engineering and } \\
\text { bionic limbs }\end{array}$ & $\begin{array}{c}\text { State-of-the-art research in } \\
\text { lower-limb prosthetic } \\
\text { biomechanics socket interface: } \\
\text { A review }\end{array}$ & $\begin{array}{l}\text { Prosthetics hands from touch } \\
\text { bionics }\end{array}$ \\
\hline $\begin{array}{l}\text { Topic of } \\
\text { Research }\end{array}$ & $\begin{array}{l}\text { Fluid-Driven origami-inspired } \\
\text { artificial muscles. (Concept) }\end{array}$ & Prosthesis integration & $\begin{array}{c}\text { ower-limb prosthetic } \\
\text { biomechanics socket interface }\end{array}$ & $\begin{array}{c}\text { Details of mechanical } \\
\text { construction and available grip } \\
\text { pattern in prosthesis }\end{array}$ \\
\hline Mechanism & $\begin{array}{c}\text { It's a concept mechanism consisting } \\
\text { of three main components: } \\
\text { Compressible Skeleton, Flexible } \\
\text { Skin and Fluid Actuate. Origami } \\
\text { inspired skeleton with capability of } \\
\text { being geometrically programmable } \\
\text { to achieve pseudo sequential } \\
\text { multiaxial motion }\end{array}$ & $\begin{array}{l}\text { The technique of targeted } \\
\text { motor re-innervation first } \\
\text { reported in } 2004 \text { has become } \\
\text { one of the most important } \\
\text { advancement in prosthetics. } \\
\text { This innovative surgical } \\
\text { procedure reroutes signals } \\
\text { from nerves severed during } \\
\text { amputation to intact muscles, } \\
\text { allowing control of prosthetic } \\
\text { devices by merely thinking } \\
\text { about the action. }\end{array}$ & \begin{tabular}{|} 
Reviewed socket \\
biomechanics, including \\
socket pressure measurement, \\
friction-related phenomena \\
and associated properties, \\
computational modeling, and \\
limb tissue responses to \\
external mechanical loads and \\
other physical conditions at \\
the interface.
\end{tabular} & $\begin{array}{l}\text { Powered by internal batteries, } \\
\text { drive with the help of five } \\
\text { motors of i-LIMB, controlled } \\
\text { by myoelectric signals from } \\
\text { muscles. Maxon gearboxes and } \\
\text { a worm-and-wheel set to } \\
\text { reduce speed and increase } \\
\text { torque. }\end{array}$ \\
\hline $\begin{array}{l}\text { Tests/ } \\
\text { Proposal }\end{array}$ & $\begin{array}{l}\text { Low-cost fabrication method for } \\
\text { rapid manufacturing of artificial } \\
\text { muscles. }\end{array}$ & $\begin{array}{l}\text { Artificial prosthesis that } \\
\text { integrates with residual } \\
\text { tissues. Function based on } \\
\text { signal impulses received from } \\
\text { residual nerves. Regenerative } \\
\text { Engineering. }\end{array}$ & $\begin{array}{l}\text { Biomechanical understanding } \\
\text { of the interaction between } \\
\text { prosthetic socket and the } \\
\text { residual limb }\end{array}$ & $\begin{array}{l}\text { i-LIMB with the whole set of } \\
\text { grip patterns which makes it } \\
\text { more realistic and effective in } \\
\text { performing usual tasks. }\end{array}$ \\
\hline
\end{tabular}




\section{International Journal of Science and Research (IJSR) ISSN: 2319-7064}

ResearchGate Impact Factor (2018): 0.28 | SJIF (2018): 7.426

\begin{tabular}{|c|c|c|c|c|}
\hline Abilities & $\begin{array}{l}\text { Ability to be driven by fluids at } \\
\text { negative pressure. }\end{array}$ & $\begin{array}{l}\text { Improved responsive } \\
\text { movements and graduation of } \\
\text { muscle force. }\end{array}$ & $\begin{array}{c}\text { Socket used as a human- } \\
\text { device interface must be } \\
\text { designed properly to achieve } \\
\text { satisfactory load transmission, } \\
\text { stability, and efficient control } \\
\text { for mobility }\end{array}$ & $\begin{array}{c}\text { Fingers with } 3 \text { linear sections } \\
\text { (phalanges), individually } \\
\text { powered. Different grip pattern } \\
\text { to differentiate from power } \\
\text { grip to precision grip }\end{array}$ \\
\hline Challenges & $\begin{array}{c}\text { Factors of limiting application of } \\
\text { existing artificial muscle concepts: } \\
\text { Single degree-of-freedom contractile } \\
\text { actuation motions and expensive } \\
\text { material. }\end{array}$ & $\begin{array}{l}\text { Interfering with biological } \\
\text { processes with biological } \\
\text { technologies, engineering } \\
\text { biological control with } \\
\text { electronic systems and } \\
\text { feedback calibrations. } \\
\end{array}$ & \begin{tabular}{|c|} 
A deep understanding of \\
prosthetic biomechanics which \\
consists of the metal/bone and \\
metal/skin interfaces along \\
with technical and \\
biomechanical interfaces. \\
\end{tabular} & \\
\hline Material & $\begin{array}{c}\text { Article mentions Shape memory } \\
\text { alloys (SMAs), Twisted Fishing } \\
\text { Line Polymer, Sewing Thread. } \\
\text { Materials mentioned generates large } \\
\text { stresses }\end{array}$ & $\begin{array}{c}\text { Electromyogram signals } \\
\text { (EMG Signals) ; Bock's } \\
\text { ActiGait System; Longitudinal } \\
\text { Intrafascicular electrodes } \\
\text { (LIFEs); Silicon-based MEA } \\
\text { shanks }\end{array}$ & $\begin{array}{c}\text { Elastomeric liners and flexible } \\
\text { thermoplastic sockets alter the } \\
\text { load transferred. }\end{array}$ & $\begin{array}{l}\text { Fingers are covered by } \\
\text { injection moldedZytel product } \\
\text { from Du Pont, covered with } \\
\text { flexible "skin"(cosmesis } \\
\text { gloves) }\end{array}$ \\
\hline $\begin{array}{l}\text { Results and } \\
\text { Findings } \\
\text { From } \\
\text { Literature } \\
\text { review }\end{array}$ & \begin{tabular}{|} 
Experiments mentioned in the article \\
reveals $90 \%$ contraction of initial \\
length of muscle, stress generation \\
of $600 \mathrm{kPa}$ and peak power density of \\
$2 \mathrm{~kW} / \mathrm{Kg}$; equivalent to natural \\
muscle.
\end{tabular} & $\begin{array}{l}\text { High scope of experimentation } \\
\text { in Bionic hand. The } \\
\text { regenerative toolbox will } \\
\text { facilitate convergence of } \\
\text { discrete disciplines to effect } \\
\text { guided tissue regeneration } \\
\text { using components such as } \\
\text { scaffolds, controlled surface } \\
\text { topographies, stimulatory } \\
\text { cues, both chemical and } \\
\text { physical factors, and their } \\
\text { integration with robotic } \\
\text { systems, to restore limb } \\
\text { functionality. }\end{array}$ & $\begin{array}{c}\text { Biomechanical effects of new } \\
\text { interfaces and helping } \\
\text { prosthetists to adjust their } \\
\text { socket designs to make best } \\
\text { use of the properties of new } \\
\text { technologies. Prosthetic socket } \\
\text { designs must have an optimal } \\
\text { load distribution which is } \\
\text { proportional to the ability of } \\
\text { the body to sustain such } \\
\text { stresses without crossing the } \\
\text { thresholds of pain or skin } \\
\text { breakdown. }\end{array}$ & $\begin{array}{c}\text { Grip patterns improve } \\
\text { performance of prosthetics and } \\
\text { introduce realistic touch. } \\
\text { Individually powered fingers } \\
\text { propose advance flexibility. } \\
\text { Cosmesis have developed skin } \\
\text { which moves and flexes like } \\
\text { human skin, and forms } \\
\text { protective layer to keep dust } \\
\text { and moisture from electronic } \\
\text { and mechanical components. } \\
\text { Missing finger in an accident } \\
\text { or congenital condition fitted } \\
\text { individual Pro-digit powered } \\
\text { prosthesis. }\end{array}$ \\
\hline $\begin{array}{c}\text { Technology } \\
\text { used } \\
\end{array}$ & $\begin{array}{c}\text { Mechanism Mentioned in this article } \\
\text { uses pressure difference between } \\
\text { two fluids (internal \& external) of } \\
\text { actuating body to achieve the desired } \\
\text { motion. Overcomes shortcomings of } \\
\text { positive pressure (expansion) } \\
\text { actuated muscles by replacing it with } \\
\text { negative pressure actuated skeleton } \\
\text { (suction/vacuum) eliminating the } \\
\text { requirements of expensive skin } \\
\text { materials used for positive pressure } \\
\text { muscles to bear the pressure applied } \\
\text { (outwards/tensile strength). }\end{array}$ & \begin{tabular}{|l} 
Bock's ActiGait System; \\
Longitudinal Intrafascicular \\
electrodes (LIFEs); Silicon- \\
based MEA shanks
\end{tabular} & $\begin{array}{l}\text { CAD/CAM technology used } \\
\text { for the prosthetic socket can } \\
\text { be useful to make socket } \\
\text { design and manufacture } \\
\text { process more effective. }\end{array}$ & $\begin{array}{c}\text { i-LIMB Hand, High } \\
\text { performance microprocessor in } \\
\text { each limb, innovative software } \\
\text { installed to encounter } \\
\text { resistance. }\end{array}$ \\
\hline $\begin{array}{l}\text { Proposed } \\
\text { Field of } \\
\text { Application }\end{array}$ & \begin{tabular}{|c|} 
Author proposes concept's \\
application in the area of wearable \\
Devices and Human-robot \\
interactions.
\end{tabular} & $\begin{array}{l}\text { Regenerative Engineering, } \\
\text { Electrical stimulation }\end{array}$ & $\begin{array}{c}\text { Biomechanics (Prosthetic } \\
\text { Biomechanics) }\end{array}$ & Field of Bionics \\
\hline
\end{tabular}

Table 2

\begin{tabular}{|c|c|c|c|c|}
\hline Author/Topic & $\begin{array}{l}\text { Anissa Mota Materials of } \\
\text { Prosthetic limbs }\end{array}$ & $\begin{array}{c}\text { Charles Schmidt The bionic } \\
\text { material }\end{array}$ & \begin{tabular}{|c|} 
Rosalam Che Mea,*, \\
RahinahIbrahima,b and Paridah \\
Md. Tahira Natural based \\
composite material for prosthetic \\
socket fabrication
\end{tabular} & $\begin{array}{c}\text { Ipsita Roy and Munishwar Nath } \\
\text { Gupta Smart Polymeric } \\
\text { Materials: Review Emerging } \\
\text { Biochemical Applications }\end{array}$ \\
\hline Challenges & $\begin{array}{l}\text { To find suitable material to } \\
\text { use for prosthetic devices in } \\
\text { developing world. }\end{array}$ & $\begin{array}{c}\text { The article explains the } \\
\text { challenges faced using } \\
\text { graphene technology, but the } \\
\text { author still feels that graphene } \\
\text { is an enabling material and has } \\
\text { properties that could lead to a } \\
\text { whole new generation of } \\
\text { neural devices }\end{array}$ & $\begin{array}{c}\text { To use new material which } \\
\text { which should be more cost } \\
\text { efficient and yet maintaining the } \\
\text { features required for artificial } \\
\text { limbs }\end{array}$ & \begin{tabular}{|c|} 
In designing scaffolds which \\
influence cell adhesion, \\
differentiation, and migration \\
with specific cell types to create \\
artificial tissues
\end{tabular} \\
\hline Material & $\begin{array}{l}\text { Anita Mota, 2017, California } \\
\text { State University studied the } \\
\text { She perceives that among the } \\
\text { metal's available titanium is }\end{array}$ & $\begin{array}{c}\text { Among the bionic materials } \\
\text { graphene could be an ideal } \\
\text { basis for medical repair kit as } \\
\text { explained by Charles Schmidt. }\end{array}$ & $\begin{array}{c}\text { Rosalam et al., } 2012 \text { presented a } \\
\text { paper on natural based bio } \\
\text { composite material for prosthetic } \\
\text { socket fabrication where they }\end{array}$ & \begin{tabular}{|l|} 
Ipsita Roy \&amp; Munishwar \\
Nath Gupta et. al, performed a \\
research on Smart Polymeric \\
Materials which respond with a
\end{tabular} \\
\hline
\end{tabular}

Volume 8 Issue 6, June 2019 www.ijsr.net 


\section{International Journal of Science and Research (IJSR) ISSN: 2319-7064}

ResearchGate Impact Factor (2018): 0.28 | SJIF (2018): 7.426

\begin{tabular}{|c|c|c|c|c|}
\hline & \begin{tabular}{|c|} 
the most versatile metal used \\
for load bearing structure of \\
the prosthetic and polymers \\
are generally used for small \\
components and specialized \\
features along with carbon \\
fibers and supporting materials \\
which are biocompatible in \\
nature. The paper discusses \\
the overall impact of new \\
technology and material \\
selection which could gain \\
mobility, freedom, and life \\
back for the amputee. Further
\end{tabular} & $\begin{array}{l}2012 \text { in Graphene outlook. } \\
\text { The article outlines the } \\
\text { features of graphene material } \\
\text { and compares the silicon and } \\
\text { graphene transistors to better } \\
\text { understand few advantages of } \\
\text { graphene over the silicon } \\
\text { materials. Graphene produces } \\
\text { less intrinsic noise and is } \\
\text { impervious to harsh ionic } \\
\text { solutions in human body that } \\
\text { helps in detecting faint } \\
\text { signals. }\end{array}$ & $\begin{array}{c}\text { mainly emphasized upon socket } \\
\text { part of a prosthetic leg which can } \\
\text { be replaced with natural-based } \\
\text { bio composites. The paper also } \\
\text { discusses the low-cost } \\
\text { manufacturing techniques like } \\
\text { injection molding plastic } \\
\text { technique that could cut down } \\
\text { the manufacturing cost. Along } \\
\text { with most suitable material using } \\
\text { natural fiber-based composites } \\
\text { like kenaf, corn starch used with } \\
\text { plastic to fabricate prosthetic leg } \\
\text { sockets so that the low-income } \\
\text { wearers could afford to buy } \\
\text { them. }\end{array}$ & \begin{tabular}{|c|} 
considerable change in their \\
properties to small changes in \\
the environment. The paper \\
helps understand potential uses \\
of Smart materials such as \\
thermosensitive gel in Bio- \\
separation on Proteins, Design \\
of reusable Bio-catalysts, \\
Insulin drug delivery, Gene \\
therapy, Tissue engineering and \\
to produce molecular gates and \\
switches. One of the goals \\
behind designing smart \\
materials is to offer additional \\
attractions such as predictability \\
as well as improved ability to \\
manipulate desirable traits \\
present in assays.
\end{tabular} \\
\hline Findings & $\begin{array}{c}\text { Author mentions possibilities } \\
\text { of future research on light } \\
\text { weight and affordable } \\
\text { materials. }\end{array}$ & & $\begin{array}{c}\text { The paper helps us to understand } \\
\text { the prosthetic limb terminology } \\
\text { and introduces the manufacturing } \\
\text { methods and materials used for } \\
\text { making different parts of } \\
\text { prosthetic limb. }\end{array}$ & $\begin{array}{c}\text { Smart materials are poised for } \\
\text { take-off and will certainly } \\
\text { promise an exciting future at } \\
\text { interface of chemistry and } \\
\text { biology. }\end{array}$ \\
\hline $\begin{array}{l}\text { Results of } \\
\text { Research in } \\
\text { literature } \\
\text { review }\end{array}$ & $\begin{array}{c}\text { Author concludes that the } \\
\text { materials are carefully selected } \\
\text { based on user's needs and } \\
\text { further suggests the future } \\
\text { scope of selecting suitable } \\
\text { material for use across } \\
\text { prosthetic devices in the } \\
\text { developing world }\end{array}$ & $\begin{array}{l}\text { The article reviews the } \\
\text { graphene technology which } \\
\text { might bring the artificial } \\
\text { devices to their senses. }\end{array}$ & $\begin{array}{c}\text { The paper helps us to analyze the } \\
\text { new materials and suitable } \\
\text { manufacturing methods to design } \\
\text { and produce inexpensive } \\
\text { prosthesis. }\end{array}$ & \\
\hline
\end{tabular}

Table 3

\begin{tabular}{|c|c|c|c|}
\hline $\begin{array}{l}\text { Author/ } \\
\text { Topic }\end{array}$ & $\begin{array}{l}\text { Brian Lee1, Frank J. Attenello1, Charles } \\
\text { Y. Liu1, Michael P. McLoughlin2, } \\
\text { Michael L. J. Apuzzo1 } \\
\text { Recapitulating Flesh with Silicon and Steel }\end{array}$ & $\begin{array}{l}\text { Zach T. Harvey, CPO; MAJ } \\
\text { Benjamin K. Potter, MD; James } \\
\text { Vandersea, CPO; Erik Wolf, } \\
\text { PhD Prosthetic Advances }\end{array}$ & $\begin{array}{c}\text { Revolutionizing Prosthetics_-Phase } 3 \\
\text { and Revolutionizing Prosthetics 2009: } \\
\text { Dexterous Control of an Upper-Limb } \\
\text { Neuroprosthesis }\end{array}$ \\
\hline Challenges & $\begin{array}{l}\text { To rehabilitate patients remaining function } \\
\text { and learn new techniques and strategies to } \\
\text { perform necessary activities of daily living } \\
\text { (ADLs) }\end{array}$ & $\begin{array}{l}\text { One of the greatest challenges } \\
\text { with upper extremity prosthetics } \\
\text { has been patient acceptance. } \\
\text { Recent studies have found higher } \\
\text { replacement and use rates and } \\
\text { lower abandonment rates of } \\
\text { upper extremity prostheses }\end{array}$ & $\begin{array}{l}\text { The primary objectives for Phase } 3 \text { are: } 1 \text {. } \\
\text { Closed-loop cortical control of the MPL, } 2 \text {. } \\
\text { Development of wireless electrode arrays. } \\
\text { These two objectives involve a complex set } \\
\text { of technical, clinical, programmatic, and } \\
\text { regulatory challenges. To address these } \\
\text { challenges and to accomplish these } \\
\text { objectives, }\end{array}$ \\
\hline Material & $\begin{array}{l}\text { Study is directed towards the loss of } \\
\text { function of an upper extremity because of } \\
\text { stroke or spinal cord injury or a physical } \\
\text { loss from amputation, an individual's life } \\
\text { is forever changed, and activities that were } \\
\text { once routine become a magnitude more } \\
\text { difficult. Much research and effort have } \\
\text { been put into developing advanced robotic } \\
\text { prostheses to restore upper extremity } \\
\text { function. Because the upper extremities } \\
\text { can perform a wide variety of activities, } \\
\text { several types of upper extremity prostheses } \\
\text { are available ranging from passive } \\
\text { cosmetic limbs to externally powered } \\
\text { robotic limbs. In addition, new } \\
\text { developments in brain-machine interface } \\
\text { are poised to revolutionize how patients } \\
\text { can control these advanced prostheses } \\
\text { using their thoughts alone. For patients } \\
\text { with spinal cord injury or stroke, }\end{array}$ & $\begin{array}{l}\text { Osseointegration is an emerging } \\
\text { surgical technique for direct } \\
\text { skeletal attachment of prostheses } \\
\text { which may one day render } \\
\text { sockets antiquated and obsolete } \\
\text { for many patients. } \\
\\
\text { Traditional prosthetic knees are } \\
\text { passive in nature and are } \\
\text { designed to balance stability with } \\
\text { mobility during the gait cycle. } \\
\text { Microprocessors have helped to } \\
\text { improve the timing of this } \\
\text { balance and even anticipate } \\
\text { actions such as the stumble } \\
\text { recovery feature of the Otto } \\
\text { Bock Cleg (Minneapolis, MN). } \\
\text { Several manufacturers are } \\
\text { developing externally powered, }\end{array}$ & $\begin{array}{l}\text { They seeks to develop a revolutionary } 23 \text { - } \\
\text { degree-of-freedom upper-limb prosthesis, } \\
\text { spans multiple institutions and disciplines. } \\
\text { APL serves as the system integrator, } \\
\text { coordinating efforts among the various } \\
\text { participants, One of the revolutionizing } \\
\text { goals of the program is to produce a fully } \\
\text { neurally integrated upper-extremity } \\
\text { prosthetic. } \\
\text { RP3's program goals include developing an } \\
\text { end-toend system to capitalize on today's } \\
\text { neuroscience understanding and enable } \\
\text { tetraplegics to perform functions they } \\
\text { would normally perform with functional } \\
\text { natural limbs. Developing such a system } \\
\text { requires several system components and } \\
\text { subsystems }\end{array}$ \\
\hline
\end{tabular}

Volume 8 Issue 6, June 2019 www.ijsr.net 


\section{International Journal of Science and Research (IJSR) \\ ISSN: 2319-7064}

ResearchGate Impact Factor (2018): 0.28 | SJIF (2018): 7.426

\begin{tabular}{|c|c|c|c|}
\hline & $\begin{array}{l}\text { functional electrical stimulation promises } \\
\text { to provide the most sophisticated } \\
\text { prosthetic limbs possible by reanimating } \\
\text { paralyzed arms of these patients }\end{array}$ & $\begin{array}{l}\text { microprocessor TMR- } \\
\text { compatable elbows (Otto Bock } \\
\text { TMR Dynamic Arm, Motion } \\
\text { Control Utah TMR, and the } \\
\text { Boston TMR) for use with } \\
\text { multiple simultaneous inputs, } \\
\text { allowing simultaneous control of } \\
\text { up to several elbow functions. }\end{array}$ & \\
\hline Findings & $\begin{array}{l}\text { Electrical isolation of muscle groups } \\
\text { improves EMG signal and crosstalk } \\
\text { generated by neighboring muscle } \\
\text { contractions. This isolation can be } \\
\text { accomplished by inserting an adipo-fascial } \\
\text { flap between adjacent muscle groups. In } \\
\text { addition to motor function, sensation such } \\
\text { as touch, pressure, vibration, and } \\
\text { temperature for the missing limb is often } \\
\text { restored to the skin overlying the newly } \\
\text { reinnervated muscles. }\end{array}$ & $\begin{array}{l}\text { TMR-compatible elbows can } \\
\text { process the signals from multiple } \\
\text { inputs simultaneously. } \\
\text { Advanced pattern recognition } \\
\text { (APR) refers to the use of } \\
\text { computer algorithms to decipher } \\
\text { surface electrode data and } \\
\text { subsequently associate specific } \\
\text { signal patterns with the } \\
\text { appropriate prosthesis response } \\
\text { for patients. } \\
\text { A number of new implantable } \\
\text { electrodes have been developed } \\
\text { to improve myoelectric device } \\
\text { control. It amplify peripheral } \\
\text { nerve signals and thus improve } \\
\text { the responsiveness via a more } \\
\text { reliable neuromuscular unit- } \\
\text { prosthesis interface and/or } \\
\text { permit the reception of signals } \\
\text { from individual muscle groups, }\end{array}$ & $\begin{array}{l}\text { SA algorithms have been developed to take } \\
\text { single unit activities and local field } \\
\text { potentials from the primary motor and } \\
\text { premotor cortex to decode an entire suite of } \\
\text { dexterous movements, such as individual } \\
\text { flexion/extension of each finger and grasps. } \\
\text { Key accomplishments associated with this } \\
\text { cortical stimulation research include the } \\
\text { following: Characterization of safe and } \\
\text { effective stimulation pulse characteristics, } \\
\text { Team defined charge-balanced, biphasic, } \\
\text { and interpulse interval durations and } \\
\text { amplitude attributes. } \\
\text { Contact detection and pressure and location } \\
\text { discrimination: }\end{array}$ \\
\hline $\begin{array}{l}\text { Results of } \\
\text { Research } \\
\quad \text { in } \\
\text { literature } \\
\text { review }\end{array}$ & $\begin{array}{l}\text { Advanced robotic prosthetic technology is } \\
\text { flourishing, promising to transform } \\
\text { functional neuro-restoration. Options } \\
\text { available to patients with upper extremity } \\
\text { dysfunction or limb loss are expanding. } \\
\text { These advances make it possible for } \\
\text { patients to improve quality of life, recover } \\
\text { function, and regain independence. } \\
\text { Exciting advances in robotic prosthetic } \\
\text { technologies are certain to revolutionize } \\
\text { patient treatment. }\end{array}$ & $\begin{array}{l}\text { As advanced surgical techniques } \\
\text { become more mainstream, } \\
\text { continued prosthetic component } \\
\text { advancements will also be } \\
\text { required. The ultimate goal of } \\
\text { prosthetic science is to restore each } \\
\text { amputee to his or her pre-morbid } \\
\text { level of function; towards this end, } \\
\text { much work remains to be done. }\end{array}$ & $\begin{array}{l}\text { The MPL is a highly advanced robotic } \\
\text { prosthetic upper extremity capable of gross } \\
\text { movements and highly dexterous fine } \\
\text { manipulation. Coupled with neural control } \\
\text { algorithms, the MPL enables users to perform } \\
\text { limb movements through control. }\end{array}$ \\
\hline
\end{tabular}

\section{Decision Modeling and Discussion}

Notional Multi-Attribute Utility Theory (MAUT) decision analysis was conducted of the most promising and cost affordable prosthetic products, compared to the baseline of no prosthetics and some future hybrid products. Utility was based on weighting and scoring all the metrics below to compare prosthetic alternatives. From this analysis, we project future product development for bionic prosthetics.

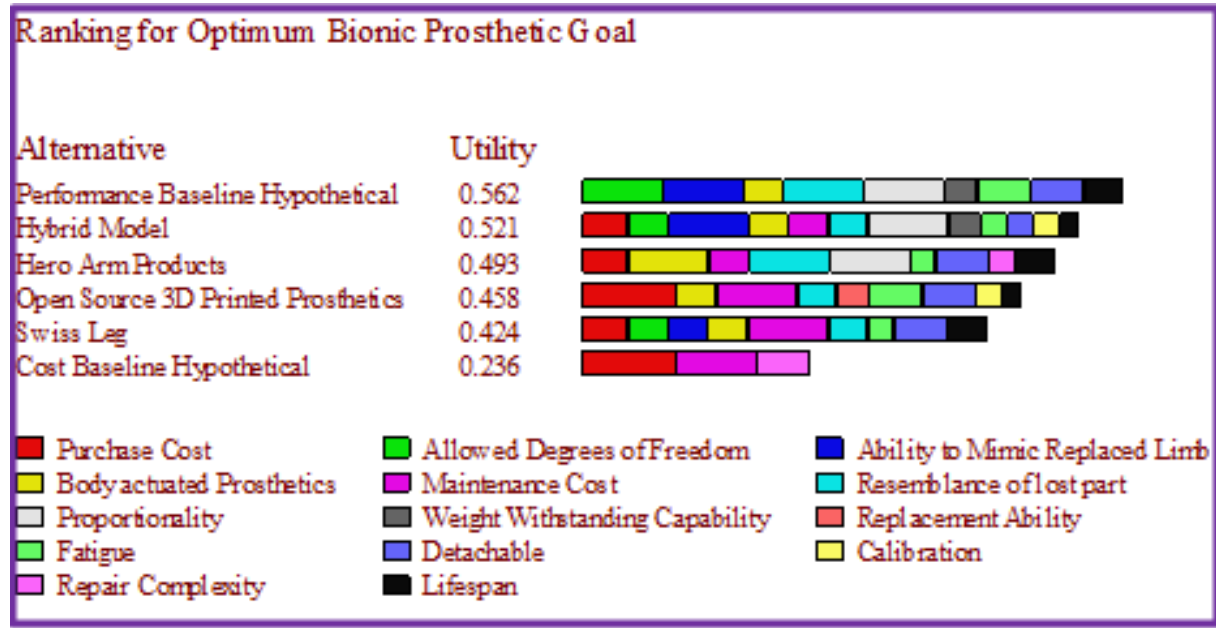

Figure 3: Notional Prosthetic Alternatives Ranking

Volume 8 Issue 6, June 2019 www.ijsr.net

Licensed Under Creative Commons Attribution CC BY 


\section{International Journal of Science and Research (IJSR) \\ ISSN: 2319-7064}

ResearchGate Impact Factor (2018): 0.28 | SJIF (2018): 7.426

Furthermore, we compare performance (functionality, serviceability, durability and ease-of-use) with primarily cost and secondarily aesthetics. The goal structure with absolute weights shown by goal (boxes) and metrics (ovals) is shown to the right.

Cost and Performance typically have an inverse value relationship. To increase prosthetic performance, one must increase cost which reduces the overall value. Dependent on the global region, the same cost and performance mix may radically differ in real value to the end consumer of prosthetic products.

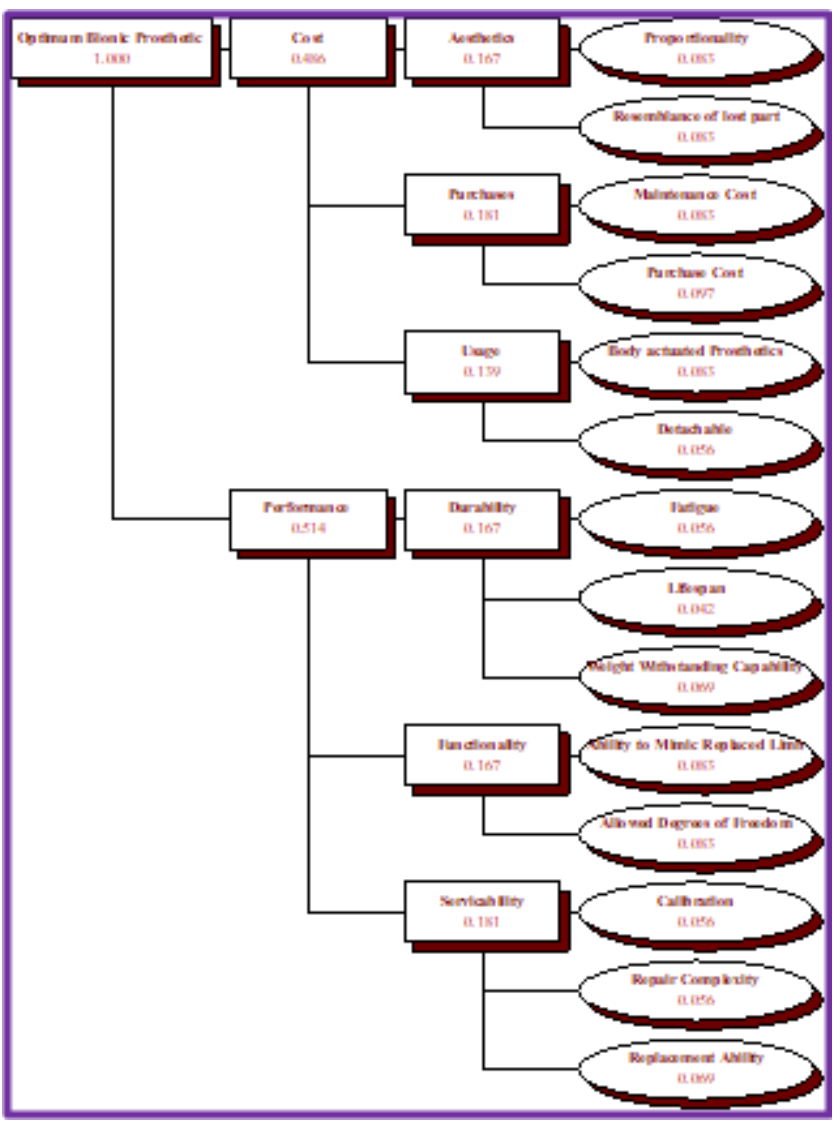

Figure 4: Notional Prosthetic Goals Hierarchy

\section{Discussion}

So far, material, prosthetic human compatibility, functionality and cost are the biggest hurdles. At present, it is now possible to achieve the real-life motion of lost limbs, but not affordably. Thus, cost concern is driving inexpensive prosthetics such as Jaipur Leg, Nepal Hand and Swiss leg. As a trade-off, these prosthetics have limitations when it comes to functioning same as a lost limb.

The amputation of a limb, whether upper or lower, is an extremely traumatic experience for the patient and carries both emotional and physical side effects with it. Once finally adjusted to a prosthetic limb, a patient then encounters numerous health issues, such as skin infection and muscle strains. Recent advancements in bionic limbs point toward a brighter future for prosthetic users, as these devices both replicate the missing body part and respond to brain signals just as the replaced limb would. Bionic limbs also allow users to perform a much wider array of motions, including dancing and climbing.

[Li 2017] proposes artificial muscles inspired by origami (Japanese paper art) and actuated by fluid gives a direction towards having prosthetics powered by these artificial muscles. Similar studies have been done by Professor Dieter Mankau at the Hochschule fürGestaltung in Offenbach show promising results specifically in prosthetic development. Application of this can be seen by the FESTO Robotics in Bionic handling assistant (elephant trunk) that showcases the capabilities of such concept. But the shortcoming with this technology is the inability to pressurize the power fluids by an actuator required to be as small as the size and energy of human heart. R\&D in micro-power applications is an ongoing research need.

"Another likely blockbuster bionic solution is brain-powered prosthetics that can completely replace the function of a lost limb through activation of brain-controlled interface."

[James 2017] talks about the controls aspect of prosthetic inspired by actual functionality of limbs using signals from nervous system. That is to reconnect nerve endings using electrodes and encode received Electromyogram signals (EMG Signals) to act as a logic operator.

The method as such, opens doors for physically lesser complex human-machine interface, but it would have several calibration complications with the nervous system. This method requires sophisticated surgery to expose neurons and have a socket installed in bones for lost limb attachments. Nano-surgical procedures and Nano-therapy are implied future research efforts.

The present prosthetics technology which is primarily modification of earlier work. Step by step these developments continue to evolve and improve over time. According to Prosthetics Advances, the United States patented the first suction suspension valve in 1863, utilizing it until World War II. Germany expanded the use of the suction knee for military amputees. In 1970, the German company Otto-Back introduced lightweight, modular endoskeleton components that could easily be aligned, which are still being modified and developed today. The same article talks about the advancement in Targeted muscle reinnervation (TMR) where motor nerves whose primary target muscle groups have been lost, are re-implanted into deliberately enervated proximal muscles. This was the new advance, at Frontier, where his technique increases the number of control sites allowing for simultaneous control of multiple movements. Natural attempted movements result in corresponding expected movement of the prosthesis. [Schmidt 2012] propose there is less need for relearning and remapping of muscle actions. Further evolution in the development of getting muscles to respond, the when they implanted their first patient, a subject with a neurodegenerative condition that prevents them from controlling their upper and lower extremities. The experience gained with this patient includes insight into the nature of human subject research with the MPL and a sense for how such a system can improve the lives of tetraplegics. As Prosthetic advances state, as advanced surgical techniques become more mainstream, continued prosthetic 


\section{International Journal of Science and Research (IJSR) \\ ISSN: 2319-7064}

ResearchGate Impact Factor (2018): 0.28 | SJIF (2018): 7.426

component advancements will also be required. The goal of prosthetic science is to restore each amputee to his or her pre-morbid level of function; towards this end, much work remains to be done.

Cardiac bionics is a recent entrant to the field of bionics for emerging markets and has already established its credibility in addressing a range of debilitating disorders such as ischemic heart disease, necessitating invasive interventions. In addition, bionic devices for chronic obstructive pulmonary disorder (COPD) involve minimally invasive devices that mimic the function of lungs.

\begin{abstract}
Making artificial limbs lifelike
Although some amputees like the robotic appearance of prosthetic components, most prefer a limb that is lifelike and therefore inconspicuous. The same silicone materials that contribute to socket comfort have also been used to create incredibly realistic external coverings for both upper and lower limb devices. The present state of the art is the creation of a care- fully sculpted match for the opposite limb, with individual coloring to give a lifelike finish.Unfortunately, such custom made prosthetic "skins" are costly (about \$3500), particularly since they need replacement after a few years because of unavoidable wear and tear from normal use. Silicone is also a relatively heavy material, so thesearch continues for a lightweight alternative, ideally offering greater flexibility and durability. Because of the costs involved, most amputees currently receive "semi-custom" external coverings that are mass produced industrially from less expensive materials and provide only a generic external appearance.
\end{abstract}

\section{The potential of low cost, limited function prostheses}

Makers of bionic prosthetic arms and legs also fight an uphill financial battle. "You have a high-end product with a small market and that does make it challenging,"

Then there's the cost of purchasing a prosthetic limb or artificial organ. A recent study published by the Worcester Polytechnic Institute found that robotic upper limb prosthetics cost $\$ 20,000$ to $\$ 120,000$. Although some private insurance companies will cover 50 to 80 percent of the fee, others have payment caps or cover only one device in a patient's lifetime. Insurance companies are also known to question whether the most advanced prosthetics are "medically necessary."

Herr believes that insurance providers need to radically rethink their cost-benefit analyses. Although the latest bionic prosthetics are more expensive per unit than less-complex devices, he argues, they reduce health care payouts across the lifetime of the patient. "When leg amputees use low-tech prostheses, they develop joint conditions, knee arthritis, hip arthritis, and they're on continual pain medication," says Herr. "They don't walk that much because walking is difficult, and that drives cardiovascular disease and obesity.

More we talk about prosthetics, we must cover the topic of materials, as they also evolve during time and now technology talks about Biomaterials, to get the senses back to the amputee however, with this biomaterial they have strived to illustrate the versatility and potential of these materials. Indeed, one could postulate that the versatility of smart materials is limited only by the imaginations of their designers and by the scientists who use them. Interestingly, a recently published article discussing the "intelligence" of smart materials hypothesized that if current smart materials were rated using a standard IQ test, they would have an IQ of 2 -impressive for inanimate compounds. And researchers are continuing to develop smarter, more useful compounds.

While there are many bionic devices at various stages of commercialization, their adoption rates are modest, with the exception of robotic exoskeletons for rehabilitation. In North America, companies such as Advanced Bionics, ReWalk Robotics and Medtronic have been successful in increasing the large-scale adoption of bionic prosthetics, achieving impressive market penetration.

\section{Conclusion}

The promising developments in lower-limb prostheses have allowedexperts to feel optimistic. With vast room forimprovement in lower-limb prostheses,it encourages researchgroups to include cutting-edge technologyin all prosthetic components. This paves the wayfor improvements in prosthetic fabricationas well as other fields thatrequire similar technology.The R\&D of lower-limb prostheses demands multidisciplinary research that requires collaborative cross-field research. Myoelectric controlled prosthetic limbs, considered to be the most exciting developmentin the field, need incorporationof mechanical moving parts,electrical circuits, bioelectronics, andmaterial science. The myoelectric-controlledprosthetic limbs function by usingelectrical signals from the amputee'snerves to the prosthesis, similar to the natural leg. While lower-limb prosthetics are increasingly sophisticated, they need to balance implicitly, elegance and cost. Growth inthe number of manufacturers of theseprosthetics is seen throughout theworld. Every product that improvesthe usability and reliability for theamputee is a societal win-win. Extensive researchis underway on implantable stumps, which may eradicate the need for asocket. With parallel developments in nanotech, bioprinting, prosthetics, and robotics,superhuman-like body parts will nolonger be fantasia.

Most of these technologies require time. The field of bionic prosthetics is of continuous development and despite human desire over time especially since World War I, there has been no significant improvement until now. With availability of modern technologies and advancement in the field of biomedical engineering, new possibilities are being discovered. The devising of replacement limbs with real lifelike capabilities is a reachable dream. Various articles talk about such discoveries and challenges that are being faced by researchers.

The future development of prostheses will depend greatly on demand. The market for low cost, limited function devices will continue to expand to meet the needs of the developing world, as well as the funding restrictions common in all economies. Innovative technologies will continue to be adapted from the aerospace and computer industries. Their application to high performance artificial limbs, will create 


\section{International Journal of Science and Research (IJSR) \\ ISSN: 2319-7064}

ResearchGate Impact Factor (2018): 0.28 | SJIF (2018): 7.426

more natural limb function. Currently, prosthetic innovations are used sparingly, primarily by amputees with private funding, particularly those who are competitive athletes. As research continues, manufacturers will apply the same principles reducing cost less active individuals in the greater market. The performance of prosthesis, particularly bionics will improve as a result. Furthermore, newer materials, high power nanotech and applications will be used for the benefit of amputees in developing countries, despite differences in the cause of amputation and people's needs. Financial constraints limit the rate of advancement in prosthetics, and one of the greatest challenges for the new millennium will be to find the will and the way to fund widespread application of prosthetic innovations. Our analysis shows the trade-offs required to balance performance, cost and aesthetics for future prosthetics bionic product development. The notional decision model that was developed shows the movement of cost vs. performance value. As the cost impact increases (moving right) higher performance and more costly solutions become lower in total value. See Figure 5 below.

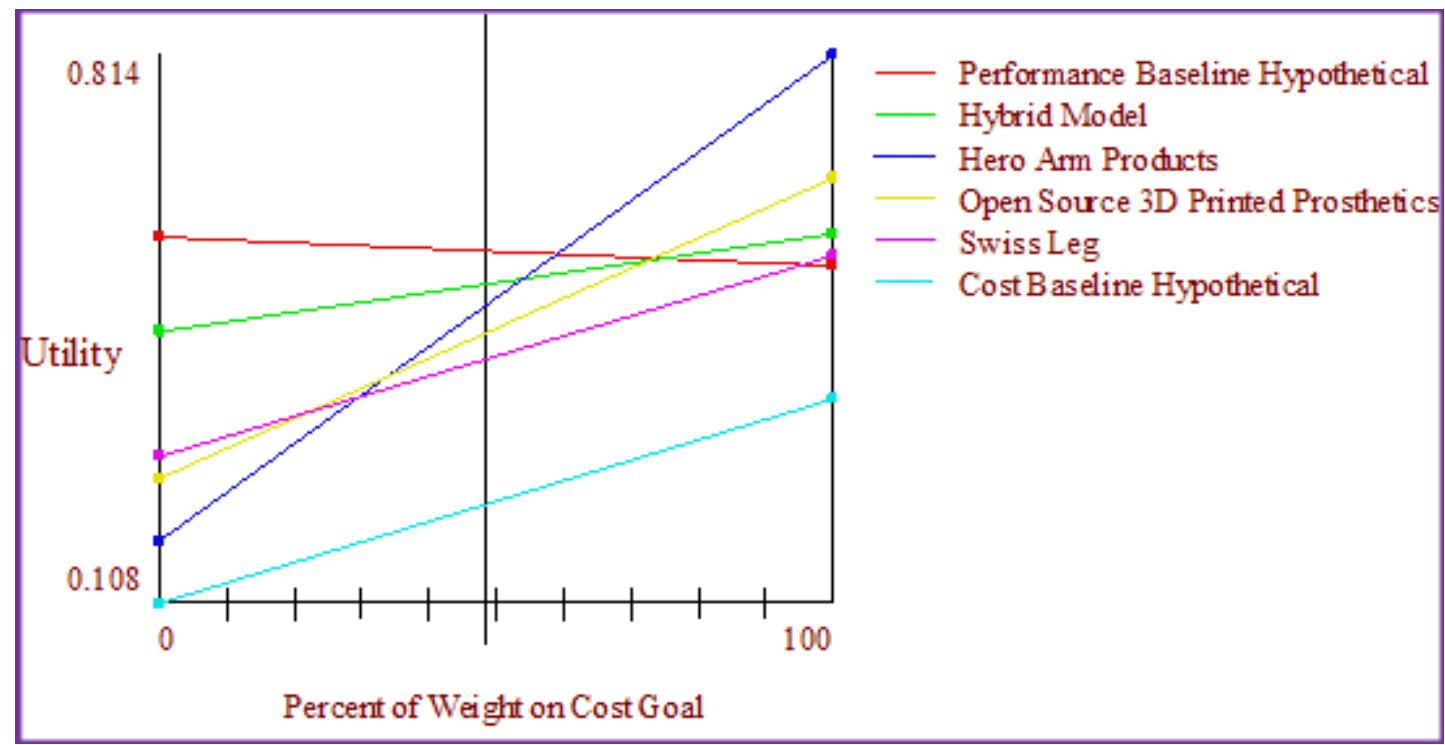

Figure 5: Cost Sensitivity on Prosthetic Total Value

The real challenge for prosthetic product development will be to balance cost and performance not only in materials, but also in improved prosthetic mechanism employment.

\section{References}

[1] Li, Shuguang, et al. "Fluid-Driven Origami-Inspired Artificial Muscles." Proceedings of the National Academy of Sciences, vol. 114, no. 50, 2017, pp. 13132-13137., doi:10.1073/pnas.1713450114.

[2] James, Roshan, and Cato T. Laurencin. "Regenerative Engineering and Advanced Materials Science." MRS Bulletin, vol. 42, no. 08, 2017, pp. 600-607., doi:10.1557/mrs.2017.5.

[3] Vitali, Andrea, et al. "Design and Additive Manufacturing of Lower Limb Prosthetic Socket." Volume 11: Systems, Design, and Complexity, 2017, doi:10.1115/imece2017-71494.

[4] Connolly, Christine. "Prosthetic Hands from Touch Bionics." Industrial Robot: An International Journal, vol. 35, no. 4, 2008, pp. 290-293., doi:10.1108/01439910810876364.

[5] Abbasi, Jennifer. "Prosthetic Limbs Given Proprioception." Jama, vol. 320, no. 6, 2018, p. 539., doi:10.1001/jama.2018.10869.

[6] Aravinthan, P., et al. "Design, Development and Implementation of Neurologically Controlled Prosthetic Limb Capable of Performing Rotational Movement." Interact-2010, 2010 doi:10.1109/interact.2010.5706148.
[7] Mangera, Taahirah, et al. "Light Metals for the Functional Requirements of Developing World Lower Extremity Paediatric Prosthetics: A Review of Current Material \& Technology Trends." Materials Science Forum, vol. 828-829, 2015, pp. 499-505., doi:10.4028/www.scientific.net/msf.828-829.499.

[8] Schmidt, Charles. "Bioelectronics: The Bionic Material." Nature, vol. 483, no. 7389, 2012, doi:10.1038/483s37a.

[9] Me RC, Ibrahim R, Tahir PM. Natural based biocomposite material for prosthetic socket fabrication. ALAM CIPTA, International Journal of Sustainable Tropical Design Research and Practice. 2012 Dec $6 ; 5(1)$.

[10]Roy, Ipsita, and Munishwar Nath Gupta. "Smart Polymeric Materials." Chemistry \& Biology, vol. 10, no. 12, 2003, pp. 1161-1171., doi:10.1016/j.chembiol.2003.12.004.

[11]Lee, Brian, et al. "Recapitulating Flesh with Silicon and Steel: Advancements in Upper Extremity Robotic Prosthetics." World Neurosurgery, vol. 81, no. 5-6, 2014, pp. 730-741., doi:10.1016/j.wneu.2014.03.012.

[12] Bridges, M \&Beaty, J \&Tenore, Francesco \& Para, M \&Mashner, Michael \& Aggarwal, V \& Acharya, S \& Singhal, Girish \&Thakor, N.v. (2010). Revolutionizing Prosthetics 2009: Dexterous Control of an Upper-Limb Neuroprosthesis. Johns Hopkins Apl Technical Digest. 28. 210-211.

[13] Ravitz, Alan D, et al. "Revolutionizing ProstheticsPhase 3." Johns Hopkins APL Technical Digest, vol. 31, no. 4, ser. 2013, pp. 366-376. 2013.

\section{Volume 8 Issue 6, June 2019 www.ijsr.net}




\section{International Journal of Science and Research (IJSR) \\ ISSN: 2319-7064}

ResearchGate Impact Factor (2018): 0.28 | SJIF (2018): 7.426

[14]Ziegler-Graham K, MacKenzie EJ, Ephraim PL, Travison TG, Brookmeyer R. Estimating the Prevalence of Limb Loss in the United States: 2005 to 2050. Archives of Physical Medicine and Rehabilitation2008;89(3):422-9.

[15] Owings M, Kozak LJ, National Center for Health S. Ambulatory and Inpatient Procedures in the United States, 1996. Hyattsville, Md.: U.S. Dept. of Health and Human Services, Centers for Disease Control and Prevention, National Center for Health Statistics; 1998.

Volume 8 Issue 6, June 2019 www.ijsr.net 